JPDN ISSN 2579-6461 (Online) ISSN 2460-6324 (Print)

Jurnal Pendidikan Dasar Nusantara

Volume $7 \mid$ Nomor $1 \mid$ Juli $2021 \mid$

DOI: https://doi.org/10.29407/jpdn.v7i1.15890

\title{
DAMPAK PEMBELAJARAN DARING TERHADAP KEMAMPUAN ANAK USIA SEKOLAH DASAR
}

\author{
Dhiniaty Gularso ${ }^{1)}$, Hadna Suryantari ${ }^{2)}$, Henry Aditia Rigianti ${ }^{3)}$, Martono ${ }^{4)}$ \\ dhiniaty@upy.ac.id ${ }^{1}$, hadna@upy.ac.id ${ }^{2}$, henry@upy.ac.id ${ }^{3}$, m9rtono@gmail.com ${ }^{4}$ \\ PGSD, FKIP, Universitas PGRI Yogyakarta ${ }^{1,2,3}$ \\ SD Negeri Rejodadi ${ }^{4}$
}

\begin{abstract}
Abstrak: Penelitian ini bertujuan untuk mendeskripsikan dampak pembelajaran daring selama pandemi COVID-19 terhadap kemampuan kognitif dan afektif anak berusia sekolah dasar. Penelitian ini dilakukan di SD Negeri Rejodadi. Penelitian ini menggunakan pendekatan kuantitatif survey dengan desain penelitian deskriptif. Teknik pengumpulan data dilakukan dengan pengisian kuesioner daring melalui Google Form. Data yang terkumpul berjumlah 124 dari 178 orang tua siswa dari kelas satu sampai kelas enam. Analisis data yang digunakan adalah pengumpulan data, reduksi, penyajian data, dan penarikan kesimpulan. Teknik analisis data yang digunakan adalah modus dan persentase. Hasil penelitian mengungkapkan bahwa pembelajaran online selama pandemi COVID-19 berdampak pada peningkatan dan penurunan kemampuan anak seperti kemampuan berpikir, bahasa, matematika, teknologi, komunikasi, fisik, dan kemampuan berdoa. Peningkatan terbesar pada kemampuan anak terdapat pada kemampuan teknologi (36\%) dan kemampuan berpikir (17\%), sedangkan penurunan terbesar pada kemampuan anak terjadi pada kemampuan berpikir (33\%) dan kemampuan fisik (19\%).
\end{abstract}

Kata kunci: pembelajaran daring, dampak pembelajaran daring, peningkatan kemampuan anak, penurunan kemampuan anak.

\section{THE IMPACT OF LEARNING DURING COVID-19 PANDEMIC TOWARD PRIMARY-AGED CHILDREN'S ABILITY}

Abstract: This research aimed at describing the impact of online learning during COVID-19 pandemic toward primary-aged children's cognitive and affective ability. The research was conducted at State Elementary School of Rejodadi. The descriptive survey of quantitative method was employed to carry out this research. The data collecting technique was done by filling out an online questionnaire through Google Form. The collected data reached were 124 of 178 parents of the students from the first to sixth grade. Data analyses used were data collection, reduction, data display, and conclusion. The data analysis technique used was modus and percentage. The research 
Dhiniaty, Hadna, Henry, Martono. Dampak Pembelajaran Daring Terhadap... reveals that online learning during COVID-19 pandemic gives impacts on children's ability improvement and decline such as thinking, language, mathematical, technological, communication, physical, and prayer ability. The greatest improvement of children ability is on technological ability (36\%) and thinking ability (17\%), while the greatest decline of children ability is on thinking ability (33\%) and physical ability (19\%).

Keywords: online learning, online learning impact, children's ability improvement, children's ability decline.

\section{PENDAHULUAN}

Corona Virus Disease-19 (COVID-19) merupakan tantangan terbesar yang harus dihadapi dalam pelaksanaan sistem pendidikan (Daniel, 2020). Terlebih setelah ditetapkannya COVID-19 sebagai pandemi, pemerintah Indonesia melalui kementerian pendidikan dan kebudayaan mengeluarkan Surat Edaran Nomor 4 Tahun 2020 terkait pelaksanaan kebijakan pendidikan dalam masa darurat penyebaran COVID-19 yang satu di antaranya memuat kebijakan terkait proses pembelajaran dari rumah. Pembelajaran yang semula dilaksanakan secara tatap muka, kini harus dilakukan secara daring guna mencegah penyebaran COVID-19.

Pada dasarnya pembelajaran daring merupakan pembelajaran jarak jauh yang disampaikan melalui penggunaan internet dan teknologi yang memungkinkan siswa dan guru saling berinteraksi satu sama lain dan bersifat fleksibel (Hoic-Bozic, Mornar, \& Boticki, 2009). Di dalam pelaksanaannya, sebagian besar guru di Indonesia memanfaatkan aplikasi tak berbayar seperti WhatsApp, Facebook, Google Classroom, e-mail, e-learning, YouTube, dan lain sebagainya untuk menyampaikan materi pembelajaran (Pajarianto, 2020). Penggunaan teknologi interaktif tersebut mampu menciptakan lingkungan belajar bagi siswa sehingga siswa bisa belajar, menerima umpan balik, dan meningkatkan pemahaman serta memperoleh pengetahuan baru (Bransford, Brown, \& Cocking, 2000).

Di balik manfaat dan keluwesannya, pembelajaran daring berdampak terhadap kemampuan dan pencapaian akademik anak dimana semakin bertambahnya usia anak, maka semakin besar pula dampaknya terhadap pencapaian akademiknya (Hoskins \& Hooff, 2005). Nguyen (2017) mengungkapkan bahwa pembelajaran daring memberikan dampak terhadap kemampuan siswa dalam berinteraksi dengan teman dan guru, 
Dhiniaty, Hadna, Henry, Martono. Dampak Pembelajaran Daring Terhadap... kemampuan menggunakan teknologi, dan kemampuan berifikir siswa dalam memahami materi yang disampaikan oleh guru. Dua pernyataan di atas dapat diartikan bahwa untuk memaksimalkan dampak positif pembelajaran daring terhadap kemampuan dan pencapaian akademik anak berusia sekolah dasar diperlukan kolaborasi yang baik antara pihak sekolah, guru, orangtua dan anak (Australian Council of State School Organization, 2008).

Lebih lanjut, anak berusia sekolah dasar tergolong dalam usia emas. Dalam usia emas ini dasar sikap, perilaku, mental, serta kecerdasan yang meliputi spiritual, intelektual, emosional, dan sosial terbentuk secara intensif (Haryadi \& Aripin, 2015). Terkait dengan kemampuan anak tersebut, kemampuan kognitif dan afektif merupakan domain kemampuan yang penting untuk dikembangkan. Anak berusia sekolah dasar hendaknya didorong untuk mengembangkan kemampuan kognitif dan afektifnya.

Kemampuan kognitif merupakan kemampuan penting yang berhubungan dengan tujuan belajar dan berorientasi pada kemampuan berpikir (Bujuri, 2018). Kemampuan kognitif meliputi kemampuan berfikir, seperti kemampuan mengingat, bernalar, menghafal, memecahkan masalah nyata, dan berkreasi yang berdampak pada perkembangan mental, emosional, dan kemampuan berbahasa anak (Bujuri, 2018).

Terkait dengan kemampuan kognitif anak di atas, anak berusia sekolah dasar hendaknya didorong untuk mengembangkan sejumlah kemampuan kognitif seperti kemampuan bahasa, numerasi, sains, finansial, teknologi, informasi, dan visual (Metiri Group, 2013). Kemudian, berkaitan dengan pembelajaran daring, dalam kemampuan berbahasa, pembelajaran daring mampu meningkatkan wawasan kosakata dan keterampilan menulis paragraf siswa sekolah dasar (Ababneh \& Lababneh, 2013). Hal ini didukung dengan pernyataan (Mike \& Mike, 2016) bahwa penggunaan internet dalam pembelajaran mampu meningkatkan keterampilan berpikir kritis siswa. Selain itu, kemampuan matematis siswa sekolah dasar mengalami peningkatan setelah diterapkannya pembelajaran daring (Miller, 2018). Pernyataan tersebut didukung oleh Presser et al, (2015) dan Reeves, Gunter, \& Lacey (2017) yang menyatakan bahwa penggunaan teknologi berupa aplikasi yang sesuai dengan materi matematis mampu meningkatkan kemampuan matematis siswa sekolah dasar. Lebih lanjut, pembelajaran daring berdampak terhadap peningkatan wawasan dan keterampilan dalam 
Dhiniaty, Hadna, Henry, Martono. Dampak Pembelajaran Daring Terhadap... menggunakan serta mengakses aplikasi pembelajaran lain secara lebih luas (OwusuFordjour, Koomson, \& Hanson, 2020).

Selain kemampuan kognitif, kemampuan afektif pada anak berusia sekolah dasar perlu dikembangkan. Kasilingam, dkk (2014) melalui Sari \& Rahmah (2019) menyatakan bahwa kemampuan afektif merupakan kemampuan yang berfokus pada perilaku dan motivasi yang dikaitkan dengan nilai-nilai di kehidupan sehari-hari. Di dalam praktik pembelajaran sekolah dasar di Indonesia, pengembangan dan penilaian kemampuan afektif didasarkan pada Kompetensi Inti 1 dan Kompetensi Inti 2. Kompetensi Inti 1 menitikberatkan pada pengembangan aspek spiritual, sedangkan Kompetensi Inti 2 menitikberatkan pada pengembangan aspek sosial.

Terkait aspek spiritual dengan pembelajaran daring, Pajarianto, dkk (2020) menyatakan bahwa pemaksimalan praktik religiusitas, dukungan guru, dan dukungan orangtua berpengaruh terhadap sikap mengatasi tekanan pikiran (stress) yang diakibatkan oleh pembelajaran daring. Sedangkan, terkait dengan aspek sosial (komunikasi), pembelajaran daring memberikan dampak terhadap penurunan kemampuan sosial secara langsung dan peningkatan kemampuan sosial secara virtual (Lynch, 1999).

Tujuan penelitian pada artikel ini adalah untuk mengetahui dampak pembelajaran daring terhadap peningkatan kemampuan kognitif dan afektif anak berusia sekolah dasar dan penurunan kemampuan kognitif dan afektif anak berusia sekolah dasar selama masa pandemi COVID-19.

\section{METODE}

Penelitian ini bertujuan mengetahui dampak pelaksanaan pembelajaran daring selama masa pandemi COVID-19 terhadap kemampuan kognitif dan afektif anak usia sekolah dasar. Penelitian ini menggunakan pendekatan kuantitatif dengan desain penelitian deskriptif. Populasi penelitian ini terdiri dari 178 orangtua dari siswa SD Negeri Rejodadi Kecamatan Kasihan Kabupaten Bantul Daerah Istimewa Yogyakarta, baik ayah maupun ibu. Pada penelitian ini, jumlah responden yang mengisi kuesioner sebanyak 124. Teknik pengumpulan data dilakukan dengan pengisian kuesioner secara daring menggunakan google form. Teknik analisis data yang digunakan yaitu modus dan persentase. Modus merupakan skor yang mempunyai frekuensi paling banyak di 
Dhiniaty, Hadna, Henry, Martono. Dampak Pembelajaran Daring Terhadap... antara skor lain dari sebuah pengukuran (Nurgiyantoro, Gunawan, \& Marzuki, 2014). Sedangkan, persentase yang digunakan diperoleh dengan membagi jumlah bagian dengan jumlah keseluruhan, kemudian dikalikan seratus persen. Angket telah divalidasi oleh ahli pembelajaran IPS dari Program Studi PGSD FKIP Universitas PGRI Yogyakarta yaitu Dr. Ahmad Agung Yuwono Putro, M.Pd.

\section{HASIL}

Survey diberikan kepada 178 orangtua dari siswa SD Negeri Rejodadi. Dari 178 orangtua tersebut, 124 di antaranya telah bersedia berpartisipasi dalam survey. Berikut hasil survey terkait peningkatan kemampuan siswa SD Negeri Rejodadi.

\section{Peningkatan Kemampuan Anak}

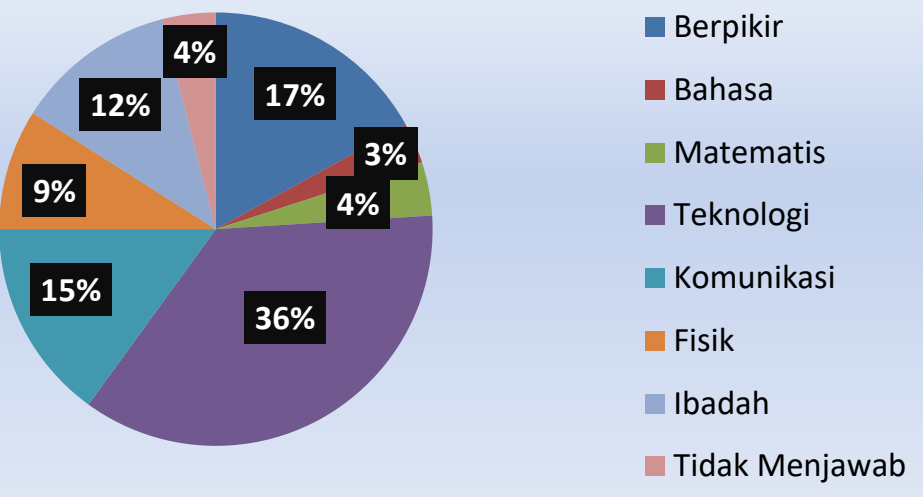

\section{Gambar 1. Peningkatan Kemampuan Anak}

Berdasarkan Gambar 1, peningkatan kemampuan anak terbesar sebagai dampak pembelajaran daring pada masa pandemi COVID-19 terdapat pada kemampuan teknologi, yaitu sebesar 36\%. Peningkatan kemampuan terbesar kedua yang dialami oleh siswa terdapat pada kemapuan berpikir sebesar $17 \%$ diikuti dengan kemampuan komunikasi (15\%), ibadah (12\%), fisik (9\%), matematis (4\%), dan bahasa (3\%). Berdasarkan hasil tersebut, $4 \%$ orangtua tidak menyatakan jawabannya terhadap peningkatan kemampuan yang dialami oleh anaknya.

Selain menunjukan peningkatan kemampuan pada anak, hasil survey menunjukan penurunan kemampuan pada kemampuan anak selama melaksanakan pembelajaran daring pada masa pandemi COVID-19. Penurunan kemampuan siswa SD Negeri 
Dhiniaty, Hadna, Henry, Martono. Dampak Pembelajaran Daring Terhadap...

Rejodadi terdapat pada kemampuan berpikir, bahasa, matematis, teknologi, komunikasi, fisik, ibadah, dan lainnya. Berikut adalah hasil survey terkait penurunan kemampuan siswa SD Negeri Rejodadi sebagai dampak pelaksanaan pembelajaran daring selama masa pandemi COVID-19.

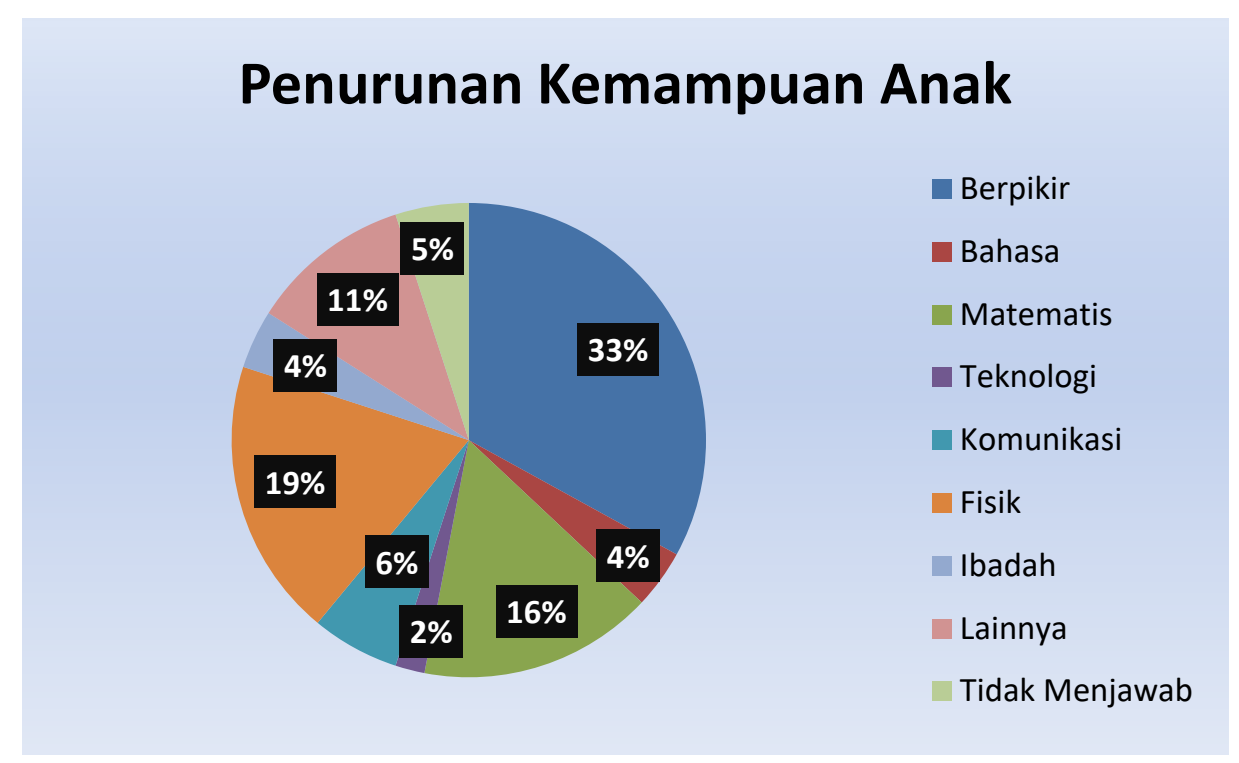

\section{Gambar 2. Penurunan Kemampuan Anak}

Berdasarkan Gambar 2, penurunan kemampuan terbesar dari siswa SD Negeri Rejodadi terdapat pada kemampuan berpikir, yaitu sebesar 33\%. Penurunan kemampuan terbesar kedua yang dialami oleh siswa terdapat pada kemapuan fisik sebesar 19\% diikuti dengan kemampuan matematis (16\%), kemampuan lainnya (11\%), komunikasi (6\%), bahasa (4\%), dan teknologi (2\%). Berdasarkan hasil tersebut, $11 \%$ orangtua tidak menyatakan jawabannya terhadap penurunan kemampuan yang dialami oleh anaknya.

\section{PEMBAHASAN}

Berdasarkan hasil dan analisis data yang diperoleh, peningkatan kemampuan anak terbesar sebagai dampak pembelajaran daring pada masa pandemi COVID-19 terdapat pada kemampuan teknologi. Cepatnya perkembangan teknologi menciptakan proses pembelajaran daring yang lebih mudah (McBrien, Jones, \& Cheng, 2009). Pembelajaran daring dipilih sebagai pilihan terbaik yang mampu menghubungkan guru dan siswa melalui perantara alat teknologi komunikasi dan akses internet. Di dalam pelaksanaan pembelajaran daring, perangkat teknologi merupakan hal penting dan bermanfaat 
Dhiniaty, Hadna, Henry, Martono. Dampak Pembelajaran Daring Terhadap... sebagai penyampai materi pembelajaran dari guru kepada siswa (Ally \& PrietoBlázquez, 2014). Akibatnya, siswa akan semakin sering bersinggungan dengan penggunaan alat teknologi karena agar dapat mengikuti pembelajaran dan mencapai hasil belajar yang maksimal siswa harus mengoperasikan alat teknologi. Bahkan, seiring dengan perpanjangan masa belajar dari rumah selama pandemi COVID-19, interaksi siswa dengan penggunaan teknologi tentu juga akan lebih lama. Hal ini membuat anak semakin terbiasa dan meningkatkan kemampuan teknologi mereka. Hasil peningkatan ini sesuai dengan pernyataan Huang (2018) bahwa semakin sering anak menggunakan teknologi di dalam pembelajaran daring, anak akan semakin mampu menguasai penggunaan teknologi tersebut. Terlebih, lingkungan belajar yang didukung dengan teknologi mampu memberikan arahan dan timbal balik kepada anak sesuai kebutuhannya (Hwang, 2014). Dengan demikian, penguasaan terhadap penggunaan dan pemanfaatan teknologi sangatlah penting. Guru dan siswa hendaknya terus berupaya meningkatkan kemampuan teknologinya di dalam proses pengajaran dan pembelajaran daring.

Selain itu, peningkatan kemampuan teknologi siswa SD Negeri Rejodadi juga didukung dengan adanya kesiapan orangtua. Berdasarkan hasil kuisioner, 74\% orangtua siap melaksanakan pembelajaran daring. Hal ini salah satunya dibuktikan dengan siapnya perangkat teknologi untuk proses belajar anak. Hasil kuisioner menunjukan bahwa seluruh orangtua dari siswa SD Negeri Rejodadi memiliki perangkat teknologi komunikasi seperti gawai android (85\%), laptop (11\%), komputer (3\%), dan gawai nonandroid (1\%).

Lebih lanjut, orangtua dari siswa SD Negeri Rejodadi sudah mampu menguasai penggunaan dan pemanfaatan media sosial atau aplikasi untuk membantu anak belajar di rumah. Media sosial yang dikuasai seperti YouTube (50\%), E-mail (18\%), Facebook (19\%), WhatsApp (74\%), Google Classroom (48\%), e-learning (5\%), dan video (27\%). Penguasaan kompetensi teknologi merupakan hal penting bagi orangtua agar mampu berpartisipasi dalam mendampingi proses belajar anak (Hollingworth et al., 2011).

Peningkatan kemampuan siswa SD Negeri Rejodadi terbesar kedua sebagai dampak pembelajaran daring pada masa pandemi COVID-19 terdapat pada kemampuan berpikir, yaitu sebesar $17 \%$. Berpikir diartikan sebagai proses mental dari perefleksian, pendugaan, pengambilan keputusan, dan analisis yang diperoleh melalui pengumpulan 
Dhiniaty, Hadna, Henry, Martono. Dampak Pembelajaran Daring Terhadap... informasi yang dipecah ke dalam komponen-komponen untuk mengungkapkan hubungan dan keterkaitan (Sabau \& Sabau, 2008). Selama pembelajaran daring, siswa melakukan proses pembelajaran dari rumah. Kegiatan pembelajaran dilakukan dengan mempelajari materi yang disampaikan oleh guru dalam bentuk tertulis maupun video pembelajaran. Dari kegiatan ini siswa belajar secara mandiri atau didampingi orangtua dalam memahami materi yang disampaikan oleh guru. Hal ini memberikan kesempatan kepada siswa untuk melatih proses berpikir mereka. Pembelajaran daring membantu siswa dalam melatih strategi belajar dan kebiasaan-kebiasaan yang akan memungkinkan mereka untuk menentukan langkah belajar dan menguasai materi oleh diri mereka sendiri (Fotiadou, Angelaki, \& Mavroidis, 2018).

Aspek peningkatan kemampuan terbesar ketiga terdapat pada kemampuan komunikasi. $15 \%$ orangtua dari siswa SD Negeri Rejodadi menyatakan bahwa anaknya mengalami peningkatan kemampuan komunikasi selama pembelajaran daring pada masa pandemi COVID-19. Penggunaan media sosial seperti WhatsApp, Facebook, Google Classroom, e-mail, e-learning, YouTube memungkinkan terjadinya interaksi antara guru dan siswa. Aktivitas interaktif di antara guru dan siswa memiliki dampak terhadap capaian pembelajaran ketika pembelajaran daring berlangsung seperti pendampingan belajar, kedekatan sosial, komunikasi pada sesi tanya-jawab dan berpendapat, serta dukungan belajar dari guru untuk siswa (Kang \& Im 2013).

Peningkatan kemampuan berikutnya adalah ibadah, fisik, matematis, dan bahasa. Berdasarkan hasil survey yang telah dilakukan, $12 \%$ siswa mengalami peningkatan kemampuan ibadah, 9\% siswa mengalami peningkatan kemampuan fisik, 4\% siswa mengalami peningkatan kemampuan matematis, dan 3\% mengalami peningkatan kemampuan bahasa. Terkait dengan peningkatan kemampuan ibadah keagamaan, Aflakseir \& Coleman (2011) menyatakan bahwa praktik dan kebiasaan beribadah memiliki dampak positif terhadap fisik dan mental beserta kesehatan keduanya. Bahkan, kemampuan ibadah keagamaan menunjukan hubungan yang positif dan signifikan terhadap tekanan akademis sehingga siswa yang memiliki kemampuan melaksanakan ibadah kegamaan yang lebih tinggi akan mampu mengendalikan tekanan belajar mereka.

Kemudian, terkait peningkatan matematis, pembelajaran daring mampu mendukung siswa dalam mengeksplor dan mengidentifikasi konsep serta hubungan matematis 
Dhiniaty, Hadna, Henry, Martono. Dampak Pembelajaran Daring Terhadap... apabila guru dapat memberikan penjelasan yang mudah dipahami siswa dan memberikan pembelajaran yang bisa melibatkan siswa ke dalam komunikasi dan kolaborasi alat teknologi (Rajkumar \& Hema, 2016). Selain itu, untuk memaksimalkan proses pembelajaran daring dan pencapaian hasil belajar terkait kemampuan matematis, orangtua perlu mendampingi anaknya selama melaksanakan pembelajaran daring (Siegler \& Mu, 2008).

Lebih lanjut, terkait dengan peningkatan kemampuan bahasa, penggunaan media sosial dan aplikasi pembelajaran dalam pembelajaran daring yang memberikan berbagai macam aktivitas dan sumber belajar serta didukung dengan pendampingan monitor dari guru mampu meningkatkan kemampuan berbahasa dan kemandirian belajar (Soliman, 2014). Walaupun pembelajaran daring mengurangi kesempatan praktik berbahasa secara lisan, Mohammadi, Ghorbani, \& Hamidi (2011) menyatakan bahwa pembelajaran daring mampu meningkatkan kemampuan bahasa tulis siswa.

Dari hasil survey peningkatan kemampuan yang dialami siswa SD Negeri Rejodadi di atas, masih ditemukan $4 \%$ orangtua yang tidak menyatakan peningkatan kemampuan yang terjadi pada anaknya. Orangtua tersebut juga tidak memberikan keterangan apakah anaknya mengalami peningkatan lain di luar aspek peningkatan kemampuan yang disebutkan dalam survey.

Selain menunjukan peningkatan kemampuan pada anak, hasil survey menunjukan penurunan kemampuan pada kemampuan anak selama melaksanakan pembelajaran daring pada masa pandemi COVID-19. Penurunan kemampuan siswa SD Negeri Rejodadi terdapat pada kemampuan berpikir, bahasa, matematis, teknologi, komunikasi, fisik, ibadah, dan lainnya.

Penurunan kemampuan terbesar dari siswa SD Negeri Rejodadi terdapat pada kemampuan berpikir. Selama pembelajaran daring, anak diharuskan belajar di rumah melalui materi yang disampaikan oleh guru. Namun, tidak semua materi dari guru dapat dipahami dengan baik oleh anak. Dengan demikian anak tetap membutuhkan pendampingan baik dari guru maupun orangtua dalam memahami materi belajar. Bahkan, pendampingan belajar oleh orangtua kepada anak merupakan suatu kewajiban (Emmy, 2008).

Keterlibatan orangtua merupakan faktor penting dari pemahaman belajar dan pencapaian belajar siswa (Loucks, 1992). Penurunan kemampuan berpikir siswa SD 
Dhiniaty, Hadna, Henry, Martono. Dampak Pembelajaran Daring Terhadap...

Negeri Rejodadi ini didukung dengan adanya realita bahwa $42 \%$ orangtua mendampingi anaknya belajar selama 2 jam yang dimulai dari pukul 19.00 hingga pukul 21.00. Minimnya pendampingan oleh orangtua tersebut dipengaruhi oleh latar belakang pekerjaan orangtua siswa yang $45 \%$ bekerja sebagai buruh dan $33 \%$ sebagai karyawan swasta. Hal ini menunjukan bahwa orangtua lebih banyak menghabiskan waktu pagi hingga sore untuk bekerja dan sisa waktunya untuk mendampingi anak belajar. Dengan demikian anak lebih sering melakukan pembelajaran daring secara mandiri.

Lebih lanjut, (Magwa \& Mugari, 2017) menyatakan bahwa semakin besar wawasan pengetahuan yang dimiliki oleh orangtua, maka semakin mudah pula orangtua memberikan pendampingan dan memahamkan anaknya dalam proses belajar. Namun, berdasarkan jenis pekerjaan yang dimiliki oleh sebagian besar orangtua dari siswa SD Negeri Rejodadi, buruh dan karyawan swasta, menunjukan bahwa orangtua siswa tidak memiliki pengetahuan terkait materi pelajaran SD yang mumpuni serta keterampilan pedagogi yang mencukupi. Hal ini memberi peluang kekurangmampuan orangtua dalam membantu memahamkan anaknya terhadap materi pembelajaran yang disampaikan oleh guru. Dengan demikian, untuk memaksimalkan dampak positif pembelajaran daring terhadap kemampuan dan pencapaian akademik anak berusia sekolah dasar diperlukan kolaborasi yang baik antara pihak sekolah, guru, orangtua dan anak (Australian Council of State School Organization, 2008).

Penurunan kemampuan anak terbesar kedua terdapat pada kemampuan fisik. 19\% siswa SD Negeri Rejodadi mengalami penurunan kemampuan fisik akibat pembelajaran daring selama masa pandemi COVID-19. Di dalam pembelajaran tatap muka sebelum adanya pandemi COVID-19, anak memiliki kesempatan lebih banyak dalam melakukan aktivitas fisik baik selama proses pembelajaran maupun selama sesi istirahat sekolah berlangsung. Namun, ketika pembelajaran daring dilaksanakan, anak selalu dihadapkan dengan penggunaan teknologi yang mengurangi kesempatan melakukan aktivitas fisik pada anak, sehingga aktivitas fisik anak menjadi semakin berkurang dan lebih pasif. Akibatnya, anak mengalami penurunan terhadap kemampuan fisik. Hal ini sejalan dengan pernyataan Rowan dan Lilliard \& Peterson (2011) melalui Halupa (2016) bahwa terlalu seringnya menggunakan teknologi memiliki dampak kegagalan anak-anak terhadap penurunan perkembangan aspek motorik dan stimulasi sensoris. Selain itu, 
Dhiniaty, Hadna, Henry, Martono. Dampak Pembelajaran Daring Terhadap... banyaknya tugas yang diberikan oleh guru selama pembelajaran daring membuat anak merasa lebih lelah dibandingkan melakukan pembelajaran tatap muka di sekolah.

Penurunan kemampuan anak terbesar ketiga terdapat pada kemampuan matematis. 19\% siswa SD Negeri Rejodadi mengalami penurunan kemampuan matematis akibat pembelajaran daring selama masa pandemi COVID-19. Sebagai salah satu mata pelajaran di sekolah, matematika dianggap sebagai mata pelajaran paling sulit (Baruah, 2015). Untuk memaksimalkan proses dan hasil pencapaian pembelajaran daring pada mata pelajaran matematika, peran keterlibatan orangtua merupakan hal yang sangat penting (Siegler \& Mu, 2008). Namun, berdasarkan hasil survey yang telah dilakukan, $46 \%$ orangtua dari siswa SD Negeri Rejodadi 2 mengalami kesulitan dalam mendampingi belajar matematika pada anaknya. Orangtua masih memiliki wawasan pemahaman matematika yang terbatas serta kurang mampu memahamkan anaknya dengan baik. Dengan demikian, guru perlu memberikan materi pembelajaran dengan penyampaian penjelasan yang mudah dipahami siswa dan orangtua. Dengan cara tersebut, diharapkan agar ketika siswa belum mampu memahami materi secara mandiri, orangtua dapat membantu memahamkan anaknya, sehingga proses belajar dan hasil capaian belajar maksimal yang artinya kemampuan matematis anak meningkat.

Lebih lanjut, di dalam pelaksanaan pembelajaran daring selama masa pandemi COVID-19 berlangsung, guru memberikan tambahan latihan-latihan soal kepada siswa sebagai bentuk penjajakan pemahaman materi yang telah disampaikan dan hasil dari pekerjaan siswa tersebut sebagian besar harus dikumpulkan dalam tenggat waktu satu hari. Hal ini diharapkan mampu meningkatkan kualitas proses belajar, pemahaman siswa, dan pencapaian hasil belajar siswa. Karena, cara ini dirasa paling efektif guna melibatkan siswa di dalam kegiatan pembelajaran daring, dengan demikian hampir seluruh guru memberikan materi dan latihan-latihan soal kepada siswa. Akibatnya siswa memiliki berbagai macam tugas latihan di rumah setiap harinya. Rutinitas ini berlangsung dari ke hari dan menjadi rangkaian kegiatan yang monoton. Kegiatan belajar siswa di rumah lebih berisi kepada kegiatan mengerjakan tugas-tugas dibandingkan memperoleh masukan materi pembelajaran oleh guru.

Realita di atas menimbulkan dampak terhadap penurunan kemampuan anak. Berdasarkan hasil survey yang telah diperoleh, sejumlah $11 \%$ anak mengalami penurunan kemampuan di luar jenis kemampuan yang ditampilkan dalam survey. Di 
Dhiniaty, Hadna, Henry, Martono. Dampak Pembelajaran Daring Terhadap... dalam survey yang telah dibagikan, orangtua tersebut mengisikan penurunan kemampuan yang dialami oleh anaknya. Hasil survey tersebut menyebutkan bahwa sebagian anak mengalami penurunan motivasi belajar. Penurunan motivasi tersebut terlihat dari sikap anak yang enggan dan malas ketika waktu pembelajaran daring berlangsung. Ketika anak melakukan proses pembelajaran, anak terlihat kurang bersemangat yang mengakibatkan anak sulit diajak mengerjakan tugas, malas berpikir, sulit berkonsentrasi terhadap materi belajar, bahkan anak menunjukan rasa marah kepada orangtua. Di dalam situasi belajar saat ini, orangtua menyatakan bahwa anakanaknya menganggap kegiatan sekolah diliburkan. Selain itu, sejumlah orangtua menyatakan bahwa anaknya mengalami penurunan pengetahuan materi pembelajaran dikarenakan lebih banyaknya tugas daipada penyampaian masukan materi pelajaran oleh guru. Penjelasan dari guru dirasa kurang maksimal bagi anak. Hal ini menyebabkan anak mengalami kesulitan memahami materi, bahkan dalam memahami soal pada tugas yang diberikan. Selain itu, orangtua mengaku bahwa anaknya mengalai penurunan sosialisasi dengan teman dan lingkungan karena banyaknya tugas yang diberikan oleh guru. Di sisi lain, sejumlah orang tua turut menyatakan bahwa anaknya tidak disiplin terhadap waktu ketika melakukan pembelajaran daring. Orientasi pikiran anak lebih tertuju pada kegiatan bermain. Akibatnya, anak lebih memilih bermain terlebih dahulu yang kemudian dilanjutkan dengan belajar. Namun, ketika anak lebih memilih belajar terlebih dahulu, anak menjadi kurang fokus pada belajar karena ingin segera bermain. Akibatnya, anak mengerjakan tugas-tugas latihan dari guru secara apa adanya. Terkait dengan penurunan kemampuan anak di atas, keadaan ini sesuai dengan pernyataan UNESCO (2020) bahwa kegiatan akademik selama pandemi COVID-19 menimbulkan dampak negatif terhadap rutinitas, pola pikir, dan masa depan anak. Namun, dengan adanya pembelajaran daring saat ini hingga waktu yang belum ditentukan, ikatan antara anak dan orangtua semakin meningkat seiring dengan kegiatan kolaboratif mereka dalam aktivitas belajar yang berlangsung karena banyaknya waktu luang yang dilalui bersama (Bhamani, Makhdoom, Bharuchi, Ali, Kaleem, \& Ahmed, 2020) sehingga orangtua hendaknya selalu memberikan dukungan moril kepada anaknya (Wang, Zhang, Zhao, Zhang, \& Jiang, 2020). Lebih lanjut, untuk mengatasi permasalahan anak yang kurang disiplin dalam mengikuti pembelajaran daring, Bhamani, Makhdoom, Bharuci, Ali, Kaleem, \& Ahmed (2020) menyatakan bahwa membuat dan 
Dhiniaty, Hadna, Henry, Martono. Dampak Pembelajaran Daring Terhadap... melaksanakan sebuah jadwal khusus dengan baik akan membantu anak merasa tidak mudah lelah, lebih produktif, dan mencegah penggunaan internet dan komputer yang tidak perlu.

Penurunan kemampuan anak sebagai dampak pembelajaran daring pada masa pandemi COVID-19 berikutnya terdapat pada kemampuan komunikasi. Pada kemampuan ini, 6\% anak mengalami penurunan kemampuan. Terkait hal ini, sekolah memainkan peranan penting dalam mendisiplinkan siswa dan mengembangkan keterampilan sosial (Bhamani, Makhdoom, Bharuci, Ali, Kaleem, \& Ahmed, 2020). Namun, selama pelaksanaan pembelajaran daring pada masa pandemi COVID-19, proses pembelajaran daring dilaksanakan di rumah masing-masing. Terlebih dengan adanya himbauan dari pemerintah bahwa masyarakat, terutama orang tua dan anakanak, harus menghindari kegiatan di luar rumah untuk mencegah penyebaran COVID19. Hal ini membuat anak lebih banyak menghabiskan waktu di rumah. Keadaan ini membuat akses komunikasi antara anak dengan teman-temannya dan lingkungan sekitar semakin terbatas. Terlebih dengan proses pembelajaran daring oleh guru yang kurang mampu melibatkan anak di dalam kegiatan belajar membuat anak semakin kehilangan kesempatan untuk melakukan praktik komunikasi di kehidupan sehari-hari.

Terkait hasil survey berikutnya, 5\% orangtua tidak memberikan jawabannya atas pertanyaan terkait penurunan kemampuan anak sebagai dampak pembelajaran daring pada masa pandemic COVID-19. Tidak diketahui apakah 5\% anak tersebut sama sekali tidak mengalami penurunan atau tidak karena orangtua tidak mengisikan tanggapan pada kolom lainnya pada pertanyaan kuisioner ini.

Penurunan kemampuan anak berikutnya berupa penurunan kemampuan ibadah. Hasil survey menunjukan bahwa $4 \%$ anak mengalami penurunan ibadah. Penyebaran COVID-19 yang semakin meluas menyebabkan penutupan berbagai macam tempat umum yang salah satunya adalah tempat ibadah dan sekolah. Ketika anak mengikuti pembelajaran tatap muka di sekolah, anak memiliki kesempatan untuk melakukan praktik belajar ibadah seperti sholat berjamaah dan tadarus Al-Qur'an bersama, namun pada saat ini praktik belajar ibadah harus dihentikan. Bahkan dengan adanya himbauan dari pemerintah yang menganjurkan masyarakat untuk melakukan praktik ibadah di rumah, kesempatan anak untuk belajar praktik ibadah semakin berkurang. Hal ini membuat rumah menjadi pilihan terbaik untuk melatih anak dalam praktik beribadah. 
Dhiniaty, Hadna, Henry, Martono. Dampak Pembelajaran Daring Terhadap...

Orangtua hendaknya tetap membiasakan kebiasaan-kebiasaan praktik beribadah kepada anaknya sama seperti apa yang pihak sekolah lakukan.

Kemampuan bahasa merupakan aspek kemampuan anak yang kurang terpengaruh oleh adanya pembelajaran daring selama pandemi COVID-19. Hasil survey menyebutkan bahwa $4 \%$ anak mengalami penurunan pada kemampuan bahasa. Tarango \& Machin-Mastromatteo (2017) menyatakan bahwa kemampuan berbahasa berkaitan dengan penggunaan bahasa melalui ungkapan-ungkapan dan interpretasi konsep, pemikiran, perasaan, fakta, dan opini agar mampu menampilkan suatu diskusi baik lisan maupun tertulis. Lebih lanjut, Claire Kramsch melalui Abdulrahman \& Ayyash (2019) menyatakan bahwa kemampuan berkomunikasi dan berinteraksi melibatkan kemampuan berbahasa, tindakan, dan aktivitas-aktivitas. Adanya pandemi COVID-19 yang membatasi akses komunikasi anak dengan teman dan lingkungan sekitar mengakibatkan berkurangnya intensitas penggunaan bahasa oleh anak. Aktivitas anak kini lebih tertuju pada pemahaman materi belajar dan pengerjaan tugas-tugas yang disampaikan oleh guru sehingga menyebabkan penurunan penggunaan praktik berbahasa secara langsung.

Penurunan kemampuan anak terendah terdapat pada kemampuan teknologi, yaitu sebesar 2\%. Selama pembelajaran daring pada masa pandemi COVID-19, segala materi pembelajaran beserta tugas-tugasnya disampaikan oleh guru kepada siswa melalui penggunaan teknologi. Hal ini membuat penggunaan teknologi oleh anak semakin lebih sering. Anak yang tadinya menggunakan teknologi sebagai sarana hiburan atau bahkan sangat jarang menggunakan teknologi, kini sedikit demi sedikit mulai terbiasa menggunakan teknologi sebagai media pembelajaran. Huang (2018) menyatakan bahwa semakin sering anak menggunakan teknologi di dalam pembelajaran daring, anak akan semakin mampu menguasai penggunaan teknologi tersebut. Dengan demikian, kemampuan teknologi sebagai dampak pembelajaran daring pada masa pandemi COVID-19 menjadi penurunan kemampuan paling sedikit di antara siswa SD Negeri Rejodadi.

\section{SIMPULAN}

Pembelajaran daring pada masa pandemi COVID-19 memberikan dampak terhadap kemampuan anak. Berdasarkan hasil survey yang telah dilakukan, 124 siswa 
Dhiniaty, Hadna, Henry, Martono. Dampak Pembelajaran Daring Terhadap...

SD Negeri Rejodadi mengalami peningkatan dan kemampuan seperti kemampuan berpikir, bahasa, matematis, teknologi, komunikasi, fisik, dan ibadah. Terkait dengan peningkatan kemampuan anak, peningkatan kemampuan terbesar terdapat pada kemampuan teknologi, yakni sebesar 36\% diikuti dengan kemampuan berpikir (17\%), komunikasi (15\%), ibadah (12\%), fisik (9\%), matematis (4\%), dan bahasa (3\%), sedangkan $4 \%$ anak tidak diketahui secara pasti peningkatan kemampuan apa yang dialami. Kemudian, penurunan kemampuan anak terbesar terdapat pada kemampuan berpikir, yaitu sebesar 33\% diikuti dengan kemampuan fisik (19\%), matematis (16\%), lainnya seperti motivasi (11\%), komunikasi (6\%), ibadah (4\%), bahasa (4\%), dan 5\% sisanya tidak diketahui penurunan apa yang dialami oleh siswa karena tidak ada tanggapan dari orangtua. Lebih lanjut, pendampingan orangtua, monitor guru, dan strategi penyampaian materi dan tugas-tugas oleh guru kepada siswa terhadap proses pelaksanaan pembelajaran daring sangat diperlukan untuk memaksimalkan peningkatan kemampuan pada anak dan mengurangi penurunan kemampuannya.

\section{UCAPAN TERIMA KASIH}

Peneliti mengucapkan terima kasih kepada pihak-pihak yang telah memberikan dorongan dan masukan-masukan terhadap pelaksanaan dan penyusunan hasil penelitian ini.

\section{DAFTAR RUJUKAN}

Ababneh, S., \& Lababneh, S. (2013). The Effect of Using the Internet on EFL Elementary School Students' Writing. Journal of Education and Practice, 4(2), 103-109. https://iiste.org/Journals/index.php/JEP/article/view/4074/4109

Abdulrahman, N. C., \& Ayyash, E. A. S. A.-. (2019). Linguistic competence, Communicative Competence and Interactional Competence. Journal of Advances in Linguistics, 10(November), 1600-1616. https://doi.org/10.24297/jal.v10i0.8530

Aflakseir, A., \& Coleman, P. G. (2011). Initial development of the Iranian religious coping scale. Journal of Muslim Mental Health, 6(1), 44-61. https://doi.org/10.3998/jmmh.10381607.0006.104

Ally, M., \& Prieto-Blázquez, J. (2014). ¿Cuál es el futuro del aprendizaje móvil en la educación? RUSC Universities and Knowledge Society Journal, 11(1), 142-151. 
Dhiniaty, Hadna, Henry, Martono. Dampak Pembelajaran Daring Terhadap... https://doi.org/10.7238/rusc.v11i1.2033

Australian Council of State School Organisations. (2008). Family - School Partnerships Framework. Review, 43. http://www.familyschool.org.au/pdf/framework.pdf

Baruah, K. (2015). Learners' consistency in mathematics performance-an investigation through statistical procedure. Asian Journal of Science and Technology, 6(7), $1608-1612$.

Bhamani, S., Makhdoom, A. Z., Bharuchi, V., Ali, N., Kaleem, S., \& Ahmed, D. (2020). Home Learning in Times of COVID: Experiences of Parents. Journal of Education and Educational Development, $7(1), \quad 9$. https://doi.org/10.22555/joeed.v7i1.3260

Bransford, J.D., Brown, A.L., \& Cocking, R. (2000). How Experts Differ from Novices. In How People Learn: Brain, Mind, Experience, and School. https://doi.org/10.17226/9853

Bujuri, D.A. (2018). Analisis perkembangan kognitif anak usia dasar. Literasi, 9(1), 3750.

Daniel, S. J. (2020). Education and the COVID-19 pandemic. Prospects, 0123456789. https://doi.org/10.1007/s11125-020-09464-3

Emmy, Rosalia. (2008). Menjadi Ortu Cerdas Tips Mendampingi Anak Belajar. Yogyakarta: Kanisius.

Fotiadou, A., Angelaki, C., \& Mavroidis, I. (2018). Learner Autonomy as a Factor of the Learning Process in Distance Education. European Journal of Open, Distance and E-Learning, 20(1), 96-111. https://doi.org/10.1515/eurodl-2017-0006

Halupa, C.P. (2016). Risks: The impact of online learning and technology on student physical, mental, emotional, and social health. A paper presented at International Technology, Education, and Development Conference, November 2016 . DOI: 10.21125/iceri.2016.0044.

Haryadi, T., \& Aripin. (2015). Melatih kecerdasan kognitif, afektif, dan psikomotor anak sekolah dasar melalui perancangan game simulasi "Warungku". Andharupa Jurnal Komunikasi Visual dan Multimedia, 1(2), 39-50. 
Dhiniaty, Hadna, Henry, Martono. Dampak Pembelajaran Daring Terhadap...

Hoic-Bozic, N., Mornar, V., \& Boticki, I. (2009). A blended learning approach to course design and implementation. IEEE Transactions on Education, 52(1), 19-30. https://doi.org/10.1109/TE.2007.914945

Hollingworth, S., Mansaray, A., Allen, K., \& Rose, A. (2011). Parents' perspectives on technology and children's learning in the home: Social class and the role of the habitus. Journal of Computer Assisted Learning, 27(4), 347-360. https://doi.org/10.1111/j.1365-2729.2011.00431.x

Hoskins, Sherria L, \& van Hooff, Johanna C. (2005). Motivation and ability: which students use online learning and what influence does it have on their achievement? British Journal of Educational Technology, 31(2), 177-192.

Huang, R. (2018). Mainstreaming digital skills to embrace the digital era. Paper presented at the UNESCO Mobile Learning Week, Paris.

Hwang, G.-J. (2014). Definition, framework and research issues of smart learning environments - a context-aware ubiquitous learning perspective. Smart Learning Environments, 1(1), 1-14. https://doi.org/10.1186/s40561-014-0004-5

Kang, M., \& Im, T. (2013). Factors of learner-instructor interaction which predict perceived learning outcomes in online learning environment. Journal of Computer Assisted Learning, 29(3), 292-301. https://doi.org/10.1111/jcal.12005

Lynch, K. (1999). The social impact of on-line learning. ASCILITE99 Conference Procedings, Clayton: 1999.

Loucks, H. (1992). Increasing parent/family involvement: Ten ideas that work. NASSP Bulletin, 76(543), 19-23.

Magwa, S., \& Mugari, S. (2017). Factors Affecting Parental Involvement in the Schooling of Children. International Journal of Research and Reflection, 5(1), 74 81.

McBrien, J. L., Jones, P., \& Cheng, R. (2009). Virtual spaces: Employing a synchronous online classroom to facilitate student engagement in online learning. International Review of Research in Open and Distance Learning, 10(3), 1-17. https://doi.org/10.19173/irrodl.v10i3.605 
Dhiniaty, Hadna, Henry, Martono. Dampak Pembelajaran Daring Terhadap...

Metiri Group. (2003). Engage $21^{\text {st }}$ Century Skills: Literacy in the Digital Age. NCREL and Metiri Group: Illinois and California.

Mike, D. G., \& Mike, D. G. (2016). Internet in the schools: A literacy perspective. Journal of Adolescent and Adult Literacy, 40(1), 1-13.

Miller, T. (2018). Developing numeracy skills using interactive technology in a playbased learning environment. International Journal of STEM Education, 5(1). https://doi.org/10.1186/s40594-018-0135-2

Mohammadi, N., Ghorbani, V., \& Hamidi, F. (2011). Effects of e-learning on language learning. Procedia Computer Science, 3, 464-468. https://doi.org/10.1016/j.procs.2010.12.078

Nguyen, V. A. (2017). The Impact of Online Learning Activities on Student Learning Outcome in Blended Learning Course. Journal of Information and Knowledge Management, 16(4). https://doi.org/10.1142/S021964921750040X

Nurgiyantoro, Burhan., Gunawan., \& Marzuki. (2014). Statistik Terapan untuk Penelitian Ilmu Sosial. Yogyakarta: Gajah Mada University Press.

Owusu-Fordjour, C., Koomson, C. K., \& \& Hanson, D. (2020). The impact of COVID19 on learning-the perspective of the Ghanaian student. European Journal of Education Studies, 7(3), 88-101. https://doi.org/10.5281/zenodo.3753586

Pajarianto, D. (2020). Study from Home in the Middle of the COVID-19 Pandemic: Analysis of Religiosity, Teacher, and Parents Support Against Academic Stress. Talent Development \& Excellence, 12(2), 1791-1807.

Rajkumar, R., \& Hema, G. (2016). E-learning strategies as a way to improve Mathematics education. In K. Viyarani \& K.S. Ramakrishnan (Eds). Digital Pedagogies: The Road Ahead. Paper presented at the National Seminar on Virtual Learning Platforms in Higher Education: Developments, Directions, Issues and Challenges organized Department of Education, Bharathiar University, Coimbatore (pp. 122-126). Tirchy: The Printing House.

Reeves, J. L., Gunter, G. A., \& Lacey, C. (2017). Mobile learning in pre-kindergarten: Using student feedback to inform practice. Educational Technology and Society, 
Dhiniaty, Hadna, Henry, Martono. Dampak Pembelajaran Daring Terhadap... 20(1), 37-44.

Sabau, I., \& Sabau, M. (2008). Online Learning: Visual Thinking and Literacy. Bulletin of the Transilvania University of Brasov. Economic Sciences. Series V, 1(50), 101108.https://search.proquest.com/openview/a6fb808d1a2edf03e9be5ab057361d33/1 ?pq origsite $=$ gscholar $\&$ cbl $=105975$

Sari, I.D.P., \& Rahmah, T.H. ((2019). Virtual Discussion for EFL Students Establishing Three Domains: Cognitive, Affective, and Psychomotor. International Journal for Educational and Vocational Studies, 1 (3), 249-253.

Siegler, R. S., \& Mu, Y. (2008). Chinese children excel on novel mathematics problems even before elementary school. Psychological Science, 19(8), 759-763. https://doi.org/10.1111/j.1467-9280.2008.02153.x

Soliman, N. A. (2014). Using E-Learning to Develop EFL Students' Language Skills and Activate Their Independent Learning. Creative Education, 05(10), 752-757. https://doi.org/10.4236/ce.2014.510088

Tarango, J, \& Machin-Mastromatteo, J.D. (2017). The Role of Information Professionals in the Knowledge Economy: Skills, Profile and a Model for Supporting Scientific Production and Communication. Oxford: Chandos Publishing.

UNESCO. (2020). COVID-19 Educational disruption and response. Retrieved from https://en.unesco.org/themes/education-emergencies/coronavirus-school-closures

Wang, G., Zhang, Y., Zhao, J., Zhang, J., \& Jiang, F. (2020). Mitigate the effects of home confinement on children during the COVID-19 outbreak. The Lancet, 395(10228), 945-947. https://doi.org/10.1016/S0140-6736(20)30547-X

Presser, A. L., Vahey, P., \& Domininguez, X. (2015). Improving mathematics learning by integrating curricular activities with innovative developmentally appropriate digital apps: findings from the next generation preschool math evaluation. In SREE Spring 2015 Conference. 